\title{
Students`Conceptual Understanding through Generative Learning Model in Topic "Light"
}

\author{
Haris Rosdianto \\ Physics Education Program, University of Teacher and Education (STKIP) Singkawang \\ Singkawang, Indonesia \\ Email: harisrosdianto@yahoo.com
}

\begin{abstract}
This study aimed to determine the effect of generative learning model on the students' conceptual understanding of the topic "Light". This type of research was pre experimental study with One Group Pretest Posttest Design. The population of this research consisted of all students of class VIII in SMP 5 Singkawang city. The sample of the research consisted of the students of class VIII E the total number of 20 students and the sampling technique used was simple random sampling. The research instrument used in the form of multiple choice test. Data were analyzed by using paired ttest. From the calculation results was obtained the value of $-t_{\text {obs. }}<-t_{\text {tc.v. }}$ or $-59.73<-2.093$, then $H_{0}$ was rejected and $H_{a}$ accepted at the level of significance $\alpha=0.05$. So it can be concluded that there is an influence of generative learning model on students' concept understanding in the topic "Light".
\end{abstract}

Keywords: generative learning model, conceptual understanding

\section{Introduction}

Physics is a science that studies about natural phenomena that can be observed by the human senses. Physics contains facts, concepts, and principles based on observations about the phenomena, and all are systematically arranged. Physics, ideally, is an activity in the classroom that can arouse students' interest in the learning process and fun in learning, challenging, and can motivate students to be more active (Subana, 2011). Understanding concepts is a fundamental and important stage in a series of physics lessons, students are directly guided to understand the concepts and principles of physics. Concept is the foundation for students to understand the material given by the teacher so that students can prove it correctly in accordance with their understanding. In learning physics still many students do not understand the concepts of the material given, so that they feel that physics is very difficult, it was seen from the result of interview with the students and the subject teachers, the observation result of the learning process and the concept comprehension test (Rosdianto et al, 2017).

It needs the right solution to overcome the low conceptual understanding by applying constructivism learning model, where students are required to find concepts, process data, digest, and formulate their own thinking. This learning model is called the generative learning model (Rosdianto, 2017). The advantage of generative learning model forms the core of generative learning, the mind or the human brain is not a passive recipient of information but is actively constructed and interprets information and further draws conclusions based on that information (Osborne \& Wittrock, 1985). Generative learning involves mental activity (Ritchie \& Volkl, 2000). Mentally, someone who undertakes generative learning will follow the line of the learning process (Flick, 1996).

Based on above description, researchers were interested in conducting research entitled "Students` Conceptual Understanding through Generative Learning Model in topic "Light". This model was expected to improve students' conceptual understanding. 


\section{Methods}

The type of this research was quantitative research with pre-experimental method (Sugiyono, 2012). The design of this research was one group pretest-posttest design (Sugiyono, 2012). The research sample was treated for a certain time. Pretest was given before treatment, and posttest was given after treatment (Arikunto, 2010).

Table 1. One group pretest-posttest research design

\begin{tabular}{ccc}
\hline Pretest & Treatment & Posttest \\
\hline $\mathrm{O}_{1}$ & $\mathrm{X}$ & $\mathrm{O}_{2}$ \\
\hline
\end{tabular}

With $\mathrm{O}_{1}$ is the pretest before the treatment was given, $\mathrm{O}_{2}$ was the final test (posttest) after the treatment was given, and $X$ was the treatment of the experimental class with the generative learning model.

The population in this research was all of VIII grade students in SMP 5 Singkawang. The sample in this research was VIII E class by using simple random sampling technique. It is said simple because the sampling of the sample of the population is done randomly without considering the strata that exist in that population (Sugiyono, 2012).

The variables in this study consisted of independent and dependent variables. The independent variable in this research was generative learning model, while the dependent variable was the students' concept comprehension. The test used was in the form of multiple choices of 30 items to know the understanding of the students' concepts. The data collection instruments used were pretest and posttest. Before the tests were used in the study, a trial was done (Arikunto, 2010). The result data of the instrument test was then processed or analyzed.

For testing of data normality, Chi-square test was used (Sugiyono 2007) as shown in Equation 1.

$$
\chi^{2}=\sum_{i=1}^{k} \frac{(f o-f \theta)^{2}}{f \theta}
$$

Where fo is the observation frequency and fe the expected frequency. The test criterion used was $\mathrm{df}=(\mathrm{k}-3)$ at significance level $\alpha=0.05$ is if $x 2$ count $<x 2$ table, then the data come from a normally distributed population.

To find out to what extent the hypothesis that had been formulated was supported by the data collected, then the hypothesis must be tested. If the distribution of data are normally distributed, then the data analyzed by using paired t-test (Sugiyono, 2007) with the pair of hypotheses were:

$\mathrm{HO}$ : There is no effect of generative learning model on students' cognitive learning achievement in Newton's Law material

$\mathrm{Ha}$ : There is influence of generative learning model to cognitive student learning outcomes in Newton's Law material.

The formula used was:

$$
t_{\text {obs. }} \frac{X-Y}{\sqrt{\frac{S_{x}^{2}}{n_{x}}+\frac{S_{y}^{2}}{n_{y}}-2 r\left(\frac{S_{x}}{\sqrt{n_{x}}}\right)\left(\frac{S_{y}}{\sqrt{n_{y}}}\right)}}
$$


with the test criterion: $\mathrm{H} 0$ was accepted if $-\mathrm{tc} . \mathrm{v} . \leq \mathrm{t}_{\text {obs. }} \leq \mathrm{t}_{\text {c.v. }}$ at significance level $\alpha=0.05$ and $\mathrm{df}=(\mathrm{n}-1)$ as well as for other $\mathrm{t}$ values $\mathrm{H} 0$ was rejected. However, if the distribution of data obtained was not normal then use non-parametric statistical test (Sugiyono, 2007).

\section{Findings And Discussions}

The data presented in this study is data obtained from test result in the form of pretest and posttest. Data result obtained from pretest and posttest can be seen in table 2 .

Table 2. Pretest and posttest results

\begin{tabular}{cccc}
\hline & Pretest & Posttest & Difference \\
\hline Average & 60.67 & 74.00 & 13.33 \\
Standard Deviation & 3.02 & 2.85 & \\
Highest Score & 66.67 & 80 & \\
Lowest Score & 53.33 & 66.67 & \\
\hline
\end{tabular}

From table 2 it can be seen that the average score of posttest results is higher than that of the pretest result. This shows that the students' conceptual understanding increased after the treatment with generative learning model.

After all data were obtained, they were analyzed. The first step was to test the data normality which aims to measure whether the analyzed data is normally distributed so that it can be used in parametric statistics. The summary of normality test data pretest and posttest can be seen in table 3 .

Table 3. Summary of normality data of pretest and posttest

\begin{tabular}{ccccc}
\hline $\begin{array}{c}\text { Score } \mathrm{X}^{20 b s} \text {. } \\
\text { pretest }\end{array}$ & $\begin{array}{c}\text { Score } \mathrm{X}^{2 c . v .} \\
\text { pretest }\end{array}$ & $\begin{array}{c}\text { Score } \mathrm{X}^{20 b s .} \\
\text { posttest }\end{array}$ & $\begin{array}{c}\text { Score } \mathrm{X}^{2 c . v .} \\
\text { posttest }\end{array}$ & Normality test \\
\hline 1.616 & 5.991 & 0.78479 & 5.991 & Normal \\
\hline
\end{tabular}

From table 3 it was found that students' pretest and posttest scores were normally distributed. After it was confirmed that the data had a normal distribution, then they were subjected to parametric statistic paired t-test. From the calculation results the obtained value was $-\mathrm{t}_{\mathrm{obs}}$. $<-\mathrm{t}_{\mathrm{c}, \mathrm{v}}$, or $-59.73<-2.093$, then $\mathrm{H} 0$ was rejected and $\mathrm{Ha}$ was accepted at the level of significance $\alpha=0.05$. So it can be concluded that there is an influence of generative learning model on the students' conceptual understanding in topic "Light".

Before the teaching with the generative learning model was implemented, the learning process was more dominated by the teacher. The students were less involved in the learning process. After the generative learning model was implemented, the students became more active in following the lessons which ultimately affected the students' understanding of the concept. This is supported by Osborne \& Wittrock (1985) who state that the generative learning model gives a significant effect on the improvement of students' conceptual understanding. This is also supported by Ritchie \& Volkl (2000) which state that the application of generative learning model is effective in improving conceptual understanding. 


\section{Conclusion and Suggestions}

Based on the results and discussion it can concluded that there is an influence of generative learning model to the students' conceptual understanding in class VIII E at SMP 5 Singkawang City on topic "Light" .

\section{References}

Arikunto. (2010). Dasar-Dasar Evaluasi Pendidikan. Jakarta: Bumi Aksara. https://doi.org/10.1016/S0969-4765(04)00066-9

Flick, L. B. (1996). Understanding a Generative Learning Model of Instruction. Journal of Science Teacher Education, 7(2).

Osborne Wittrock, M. C., R. (1985). The generative learning model and its implications for Science Education. Studies in Science Education., 12(1).

Ritchie, D., \& Volkl, C. (2000). Effectiveness of Two Generative Learning Strategies in the Science Classroom. School Science and Mathematics, 100(2), 83-89. https://doi.org/10.1111/j.1949-8594.2000.tb17240.x

Rosdianto, H. (2017). Pengaruh Model Generative Learning Terhadap Hasil Belajar Ranah Kognitif Siswa Pada Materi Hukum Newton. Jurnal Pendidikan Fisika Dan Keilmuan (JPFK). https://doi.org/10.25273/jpfk.v3i2.1288

Rosdianto, H., Murdani, E., \& Hendra. (2017). The Implementation of POE (Predict Observe Explain) Model to Improve Student's Concept Understanding on Newton's Law. Jurnal Pendidikan Fisika, 6(1), 55-57. https://doi.org/10.22611/jpf.v6i1.6899

Subana. (2011). Dasar-dasar Penelitian IImiah. Bandung: CV Pustaka Setia. bandung: pustaka setia.

Sugiyono. (2007). Statistika Untuk Penelitian. bandung: alfabeta.

Sugiyono, P. D. (2012). Metode Penelitian Kuantitatif, Kualitatif, dan R\&D. bandung: alfabeta. 